\title{
Characterizing Variations in Variable Air Volume System Controls
}

\begin{abstract}
The variable air volume (VAV) system is the most popular form of heating, ventilation, and airconditioning (HVAC) system used in commercial buildings. Researchers and engineers often use VAV systems as a reference when evaluating new technologies and systems or comparing design options. However, VAV system performance varies significantly, in part because of variations among VAV system controls, so, when analyzing use cases, it is critical to accurately represent system controls in order to accurately define system performance. Unfortunately, no existing literature documents standard VAV system controls for this purpose. This paper aims to remedy this omission by characterizing the variations in VAV system controls and proposing an approach to representing VAV system baseline performance. We used EnergyPlus to model variation among VAV system controls. We use the mediumsize office reference-building model developed by the U.S. Department of Energy to demonstrate the impact of variations among controls in two U.S. climate zones and sort system performance into "good," "average," and "poor" categories.
\end{abstract}

\section{Keywords}

Variable Air Volume (VAV) System, Controls, EnergyPlus, Building Energy Performance, Building Simulation

\section{Introduction}

A single-duct variable air volume (VAV) system controls temperature in a space by varying the amount of supply air, as shown in Figure 1 [1]. Single-duct VAV systems use one of three types of terminal units: a VAV box with or without reheat coil, or a fan-powered VAV box and induction unit. These terminal units can also be categorized as pressure-dependent or pressure-independent. A pressure-dependent terminal unit controls air damper position in response to room air temperature, and airflow may increase or decrease as the upstream duct pressure varies. A pressure-independent terminal unit controls actual supply airflow through an airflow measuring device incorporated in the terminal unit, and the position of the air damper is adjusted to maintain an airflow set point in response to room air temperature. VAV system heating and cooling are provided either by a central plant or local equipment. This study focuses on VAV systems with pressure-independent VAV boxes and reheat coils.

To maintain a comfortable indoor environment, heating, ventilation and air-conditioning (HVAC) system operation is regulated to maintain a list of control-variable set points. The controls discussed in this paper refer to control sequences used to determine the values of these HVAC system set points and their associated control parameters, as well as to start or stop the equipment. 


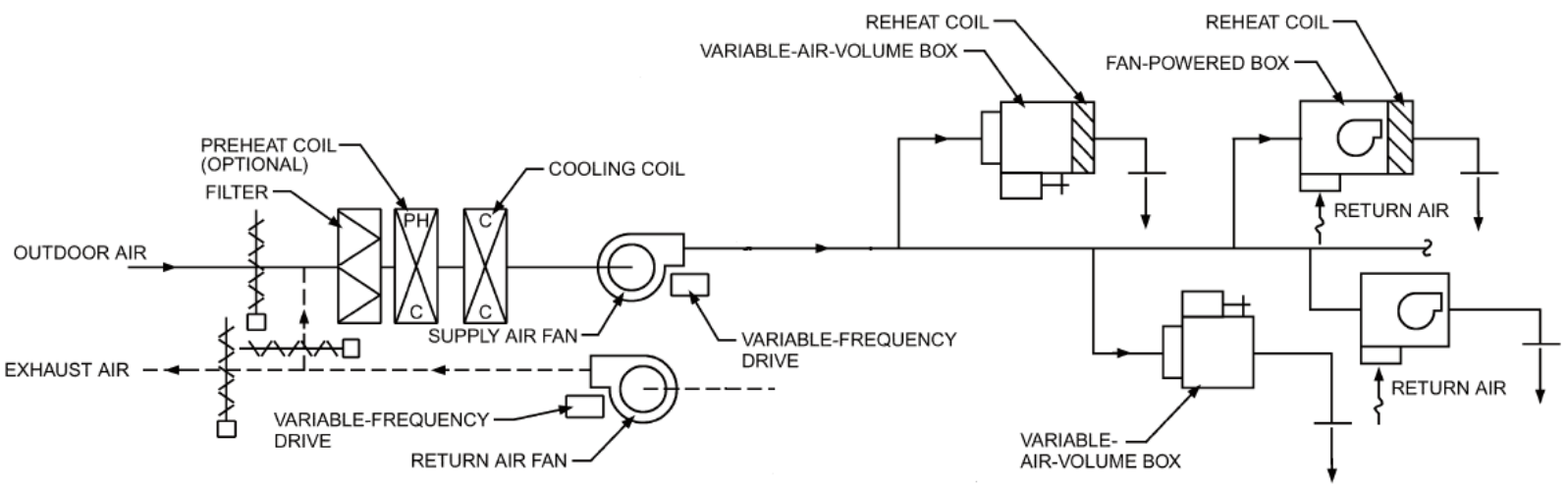

Figure 1. Single-duct VAV system with different types of terminal units source: ASHRAE Handbook - HVAC Systems and Equipment 2012

VAV systems are commonly used in large commercial buildings and considered as the most energy efficient systems in use today [2]. Therefore, researchers and engineers often use VAV systems as reference cases when developing new HVAC technologies and optimizing designs. Yao et al. [3] compared VAV systems, CAV systems and fan-coil systems, in a small office building for six different cities in China. Their simulation results showed that VAV systems can produce $17.0-37.6 \%$ energy savings when compared to the CAV systems, and 4.6-10.2\% energy savings when compared to the fancoil systems, depending on the climate. Zhou et al. [4] compared the energy performance of a variable refrigerant flow (VRF) air conditioning system with that of a VAV system. Simulation results showed that the VRF system achieved 22.2\% energy savings compared with the VAV system. Aynur [5] conducted a similar comparative study between the VRF system and the VAV system and reported that the VRF system promised $27.1 \%-57.9 \%$ energy savings potentials when compared to the VAV system. Sastry and Rumsey [6] conducted a side-by-side comparison between a VAV system and a radiant cooling system in an office building in Hyderabad, India. The office building uses two cooling systems. Half of it has a VAV system and the other half has a radiant cooling system with dedicated outdoor air system (DOAS). After two years of operation, the radiant system has used $34 \%$ less energy as compared to the VAV system.

However, the energy performance of a VAV system highly depends on the controls [7-13]. If VAV systems are used as a reference, it is critical to specify a set of control sequences that is used to establish the baseline that allows for meaningful comparisons. Any conclusion drawn from a comparison to a VAV system for which the system controls have not been explicitly defined is limited and can be misleading. Unfortunately, VAV system controls were not explicitly defined in any of the cited studies.

Our study characterizes the variations among VAV system controls and proposes an approach to defining baseline VAV system performance for different use cases. We characterize controls according to system performance as "good," "average," or "poor." Good practices are defined mainly based on [14-16]. Average and poor practices are based on expert opinions from building commissioning practitioners and researchers. We use the U.S. Department of Energy medium-size office referencebuilding model [17] to illustrate the impact on system energy performance of variation in VAV system controls. 


\section{Controls and their Variations}

Table 1 shows a common list of control variables and summarizes the range of controls. These controls are described in more detail below and are based on a conventional VAV system with direct digit control (DDC) devices, as shown in Figure 1. Some advanced features or components, e.g. airflow stations and heat-recovery wheels, are not included in this study.

\section{Occupied room set-point temperatures}

The DDC controller of a VAV box has two set-point temperatures, one for cooling and one for heating, which affect the operation of the box. The "occupied cooling set-point temperature" is the temperature in the space during occupied hours when cooling is required. The "heating set-point temperature" is the temperature in the space during occupied hours when heating is required. The cooling set-point temperature should be set higher than the heating set-point temperature to avoid rapid switching between cooling and heating operations. The difference between the cooling set-point temperature and the heating set-point temperature is referred to as the "deadband," within which the VAV box will take no action related to the damper and reheat valve. That is, the damper will remain at the minimum position to maintain the minimum airflow set point, and the reheat valve will remain closed. The "unoccupied set-point temperature" is discussed below in the "night setback" section.

Many local governments and other institutions in the U.S. mandate space temperature set points in their sustainability and energy-efficiency policies. A range of the set-point temperatures is reported from $20^{\circ} \mathrm{C}\left(68^{\circ} \mathrm{F}\right)$ to $25.6^{\circ} \mathrm{C}\left(78^{\circ} \mathrm{F}\right)$ [18-23], adapted from American National Standards Institute (ANSI)/American Society of Heating, Refrigerating, and Air-Conditioning Engineers (ASHRAE) Standard 55-2004 and 2010 [24]. The U.S. Occupational Safety and Health Administration recommends a range of $20^{\circ} \mathrm{C}\left(68^{\circ} \mathrm{F}\right)$ to $24.4^{\circ} \mathrm{C}\left(76^{\circ} \mathrm{F}\right)$ [25]. Based on the information above as well as interviews with facility managers, we chose a range of $21.1^{\circ} \mathrm{C}\left(70^{\circ} \mathrm{F}\right)$ to $23.3^{\circ} \mathrm{C}\left(74^{\circ} \mathrm{F}\right)$ to represent "average" cooling and heating set points, respectively, in U.S. office buildings. We categorize a cooling set point of $24.4^{\circ} \mathrm{C}\left(76^{\circ} \mathrm{F}\right)$ and a heating set point of $20^{\circ} \mathrm{C}\left(68^{\circ} \mathrm{F}\right)$ as "good" practice. We define "poor" practice as $22.2^{\circ} \mathrm{C}\left(72^{\circ} \mathrm{F}\right)$ for both cooling and heating set points. Specific regions might choose a different range of set-point temperatures based on local policies and practices.

\section{Night setback}

Since 1999, ASHRAE Standard 90.1 [26] has mandated setback controls. Night setbacks reduce heating and cooling set-point temperatures when a building is unoccupied or during other periods when these temperatures are acceptable. Setbacks avoid waste of energy during hours when the building is unoccupied. It allows the HVAC system to automatically restart and operate temporarily during offhours to maintain the setback temperature and thereby prevent spaces from becoming so hot or cold.

We determined the ranges of "good," "average," and "poor" setback temperatures for unoccupied buildings based on research results $[27,28]$ and good industry practices. "Average" setback temperatures were determined to be $15.6^{\circ} \mathrm{C}\left(60^{\circ} \mathrm{F}\right)$ and $29.4^{\circ} \mathrm{C}\left(85^{\circ} \mathrm{F}\right)$ for heating and cooling, respectively, "good" temperatures were $12.8^{\circ} \mathrm{C}\left(55^{\circ} \mathrm{F}\right)$ and $32.2^{\circ} \mathrm{C}\left(90^{\circ} \mathrm{F}\right)$ and "poor" temperatures were $18.3^{\circ} \mathrm{C}\left(65^{\circ} \mathrm{F}\right)$ and $26.7^{\circ} \mathrm{C}\left(80^{\circ} \mathrm{F}\right)$. 


\section{VAV box minimum airflow}

VAV boxes with reheat coils are typically controlled using single maximum control logic, shown in Figure $2[29,30]$. Supply airflow is adjusted between maximum and minimum values in response to a cooling signal. The minimum airflow rate is maintained as the space temperature falls through the deadband into heating mode. The reheat valve then opens to maintain the space at the heating set point until the valve is fully open. Single maximum control requires that the minimum airflow set point be high enough to provide design heating airflow at a reasonable supply air temperature. Thus, the minimum is typically set at $30 \%$ to $50 \%$ of the maximum airflow set point $[29,30]$. The minimum airflow set point affects thermal comfort as well as energy use. A minimum airflow set point that is too high leads to a significant amount of simultaneous heating and cooling as well as extra fan energy use. A minimum airflow set point that is too low cannot meet the heating and ventilation requirements. Based on the literature, we selected single maximum control with a $30 \%$ minimum airflow set point as "average" practice and a $50 \%$ minimum airflow set point as "poor practice" [29-31].

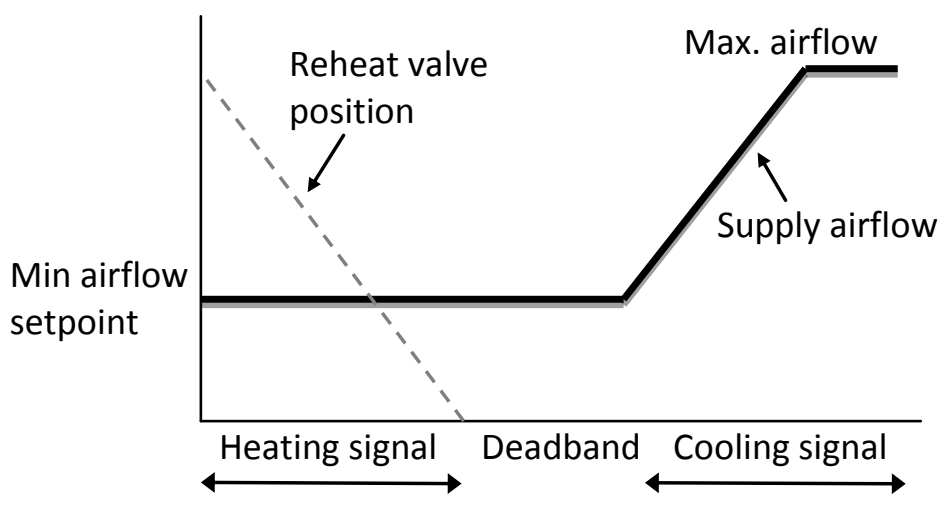

Figure 2. Single maximum control diagram

Figure 3 shows dual maximum control, which we selected to represent "good" practice [29, 30]. As the name "dual maximum" indicates, there are two maximum airflow set points, one for heating and one for cooling. The maximum heating airflow set point is typically set at $50 \%$ of the maximum cooling airflow set point. Because dual maximum control decouples the heating and ventilation requirements of the minimum airflow set points, it allows lower minimum airflow set points than are possible with single maximum control. The minimum airflow set point typically is $10 \%$ to $20 \%$ of the maximum cooling airflow set point [29]. We chose $15 \%$ as "good" practice for the minimum airflow set point. 


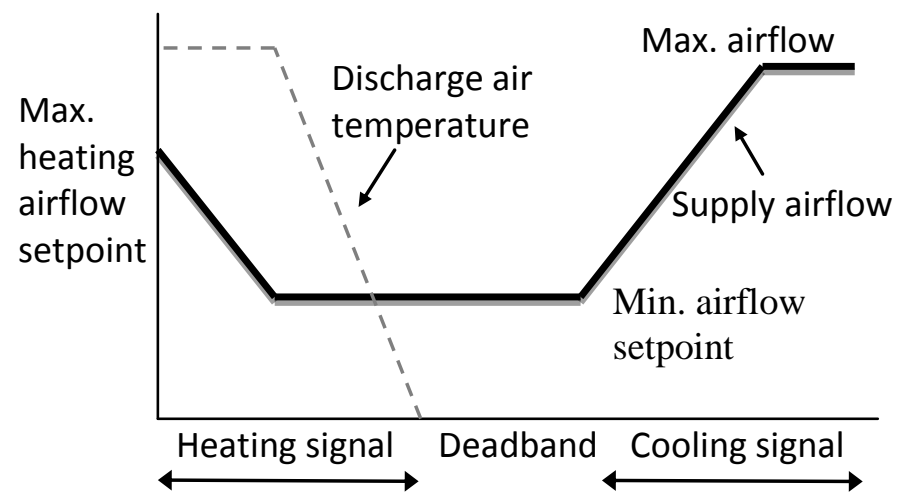

Figure 3. Dual maximum control diagram

\section{Optimum start}

When setback controls are employed, the VAV system must be started prior to occupants arriving at the building to ensure that the space is comfortable when people arrive. Ideally, optimum-start controls will start the system to provide just enough warm-up or cool-down time to bring the spaces to occupied set point temperatures at exactly the hour when occupants are scheduled to arrive, no sooner and no later [26]. This amount of time is not constant and depends on the building's heat capacity, the outdoor conditions, and the VAV system capacity. In practice, ideal control is not possible but can be approached depending on the sophistication of the control algorithm.

Self-adaptive optimum-start algorithms have been in use since the 1980s [32-34]. Many building energy management and control systems use these adaptive algorithms [35], but it often takes a few weeks at the beginning of each season to "tune" the algorithms. If an algorithm is not tuned properly, operating staff may get complaints from occupants and in response may alter the optimum start controls [36], setting the HVAC system schedule to start early enough to take care of the "worst day." This could, for example, result in a scheduled system start time of $4 \mathrm{am}$ to achieve comfortable conditions by 8am, which would only be necessary on a day with extreme temperatures and would therefore result in wasted energy on most days. Unfortunately, only a small portion of existing buildings employ adaptive optimum-start controls, and most of them employ the "worst day" schedule [36].

The average recovery time for an HVAC system is reported to be less than an hour [28, 36]. Therefore, we chose a scheduled start time of two hours earlier than the occupied start hour as "average" practice and a scheduled start time of four hours earlier than the occupied start hour as "poor" practice. "Good" practice is to use the adaptive algorithm suggested in the ASHRAE handbook [37]. The optimum start time of cooling operation is represented as:

$$
t_{o s, \text { cooling }}=a_{0}+a_{1} T_{z}+a_{2} T_{z}^{2}
$$

The optimum start time of the heating operation is represented as:

$$
t_{o s, \text { heating }}=b_{0}+(1-w)\left(b_{1} T_{z}+b_{2} T_{z}^{2}\right)+w b_{3} T_{o a}
$$


Where, $\quad T_{z}=$ zone air temperature, ${ }^{\circ} \mathrm{C}\left({ }^{\circ} \mathrm{F}\right)$

$T_{o a}=$ outdoor air temperature, ${ }^{\circ} \mathrm{C}\left({ }^{\circ} \mathrm{F}\right)$

$w=$ weighting factor, which determines weighting given to outdoor and zone air temperatures

$$
\begin{aligned}
& w=1000^{\frac{T_{s p, \text { unocc }}-T_{z}}{T_{s p, o c c}-T_{s p, u n o c c}}} \\
& T_{s p, \text { unocc }}=\text { unoccupied room set-point temperature, }{ }^{\circ} \mathrm{C}\left({ }^{\circ} \mathrm{F}\right) \\
& T_{s p, o c c}=\text { occupied room set-point temperature, }{ }^{\circ} \mathrm{C}\left({ }^{\circ} \mathrm{F}\right) \\
& a_{i}, b_{i}=\text { coefficients }
\end{aligned}
$$

The recursive linear least-square method is used to determine the coefficients based on actual recovery times on the previous days.

\section{Supply air temperature reset}

Supply air temperature (SAT) plays a key role in VAV system performance. If the SAT is too low, the airhandling unit may remove excessive latent load when mechanical cooling is operating in summer, and the VAV boxes then may need to warm up the over-cooled air before sending it to the area being served. If the SAT is too high, the fan must supply more air to the building during the cooling season, and the indoor humidity level may exceed the comfort range if the building is located in a humid climate zone. The SAT reset aims to find the optimal SAT for the full range of operational conditions to minimize the combined energy consumed by cooling, heating, and the system fan. A general guideline is to avoid turning on the mechanical cooling whenever possible. The optimal SAT should be the highest temperature that can satisfy the cooling demand and humidity level in the warmest zone. Ideally, no mechanical cooling will be required until the outdoor air temperature reaches somewhere between $15.6^{\circ} \mathrm{C}\left(60^{\circ} \mathrm{F}\right)$ and $18.3^{\circ} \mathrm{C}\left(65^{\circ} \mathrm{F}\right)$.

The "good practice" sequence of operation is to set the SAT at $12.8^{\circ} \mathrm{C}\left(55^{\circ} \mathrm{F}\right)$ when the outdoor air temperature is $18.3^{\circ} \mathrm{C}\left(65^{\circ} \mathrm{F}\right)$ and above, and to adjust the SAT between $12.8^{\circ} \mathrm{C}\left(55^{\circ} \mathrm{F}\right)$ and $18.3^{\circ} \mathrm{C}\left(65^{\circ} \mathrm{F}\right)$ as the output of a slow reverse-acting proportional-integral (PI) loop that maintains the damper in the warmest zone at $90 \%$ position when the outdoor air temperature is $18.3^{\circ} \mathrm{C}\left(65^{\circ} \mathrm{F}\right)$ and below [14]. Figure 4 illustrates the SAT "good practice" reset method.

In "average practice," the SAT is linearly reset as a function of the outdoor air temperature, with a reset schedule as shown in Figure 5 [15].

In "poor practice," the SAT is kept constant at $11.7^{\circ} \mathrm{C}\left(53^{\circ} \mathrm{F}\right)$ year round. 


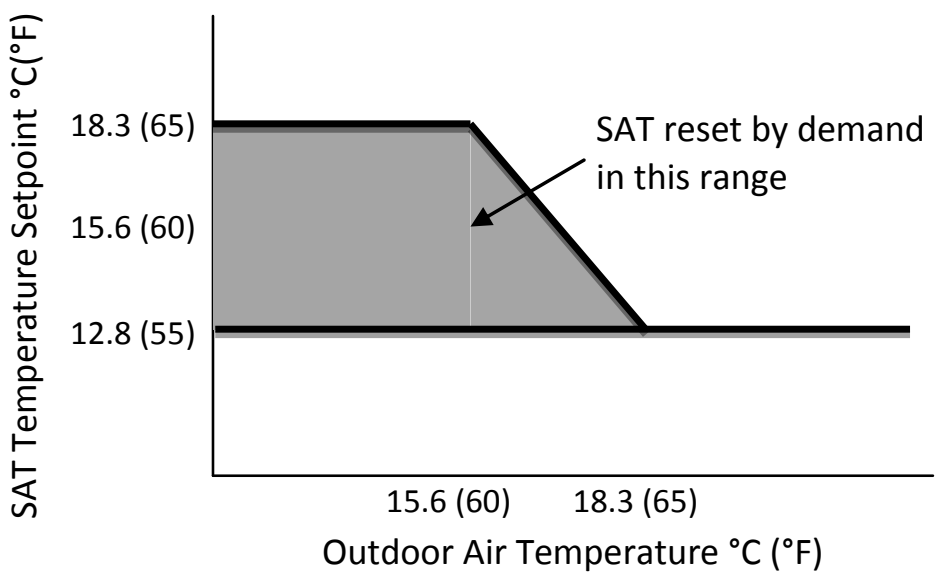

Figure 4. SAT reset method - "good practice"

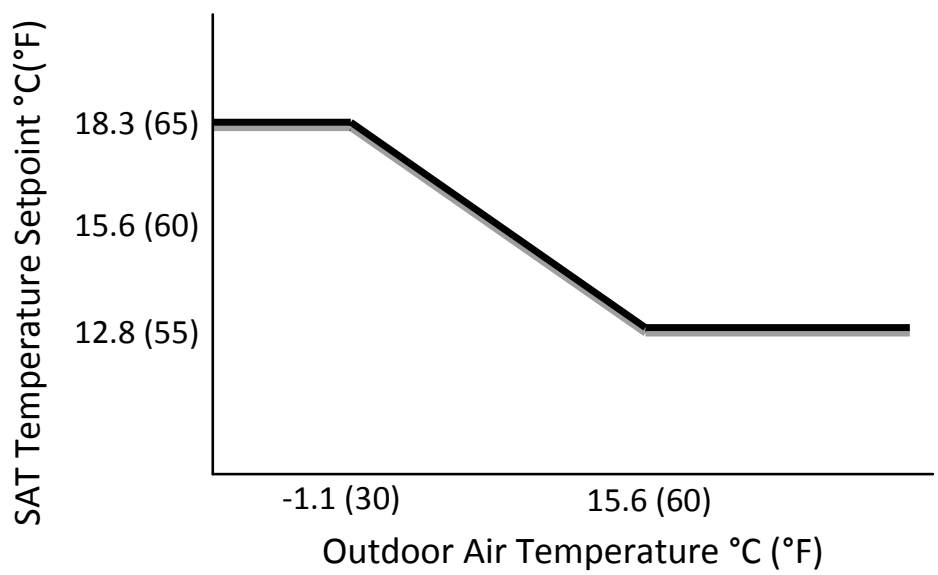

Figure 5. SAT reset schedule - "average practice"

\section{Economizer and minimum outdoor air intake}

The core zones in a commercial building require year-round cooling because of internal heat gains and no direct heat loss to the outside. Even perimeter zones may require cooling when outdoor conditions are quite cold because of significant internal heat gains and efficient envelope materials in modern buildings. The economizer is a mechanism in the air-handling unit that utilizes cold outdoor air to provide "free cooling" to a building. The economizer regulates the outdoor-air and return-air flow, maintaining the appropriate SAT by controlling the return air, outdoor air, and exhaust air dampers if present.

When outdoor-air conditions are more favorable than return-air conditions for providing "free cooling," the economizer is enabled. The most widely used economizer strategy is differential dry-bulb temperature, which compares outdoor and return-air temperatures to determine the economizer operation mode. If the outdoor temperature is lower than the return-air temperature, the economizer is enabled; otherwise, the economizer is disabled, and the dampers are controlled for minimum outdoor air. Once the economizer is enabled, the dampers are regulated to maintain the SAT set point.

A more advanced strategy is the differential enthalpy economizer, which compares the outdoor and return-air enthalpies to determine the economizer operation mode. If the outdoor enthalpy is lower 
than the return-air enthalpy, the economizer is enabled; otherwise, the economizer is disabled, and the dampers are controlled for minimum outdoor air.

We selected the differential enthalpy economizer to represent "good practice," and the differential drybulb temperature economizer to represent "average practice." We selected a scenario with no economizer operation as "poor practice."

To meet ventilation requirements, dampers are always controlled for a minimum amount of outdoor-air intake.

"Good practice" in relation to maintaining the minimum outdoor-air intake is to use a carbon-dioxide $\left(\mathrm{CO}_{2}\right)$-based demand-controlled ventilation approach that adjusts the dampers to maintain the $\mathrm{CO}_{2}$ level of the return air or of a representative zone [15]. The $\mathrm{CO}_{2}$ set point will be 500 parts per million higher than the outdoor air $\mathrm{CO}_{2}$ level. When this method is used, a minimum outdoor-air damper position must be set to ensure that the outdoor-air intake is greater than the total exhaust airflow so that the building is maintained at slightly positive pressure.

For "average" practice, the minimum outdoor-air intake requirement is met by specifying a minimum outdoor-air damper position. This is set under the system's design airflow conditions, and the damper remains in the same position throughout the full range of system operation [14]. Typically, the minimum outdoor-air damper position is between $10 \%$ and $20 \%$.

"Poor" practice is to set the minimum outdoor-air damper position at $30 \%$, which represents an overventilated scenario because of either poor control or leaky dampers.

\section{Duct static pressure}

Duct static pressure ensures that sufficient air is delivered to the space. Supply-air fan speed is regulated to maintain the duct static pressure set point.

ASHRAE Standard 90.1 [26] requires that, for systems with DDC of individual zones reporting to a central control panel, the static pressure set point must be reset based on the zone requiring the most pressure. We adopted the approach described in the standard as "good" practice. This entails resetting the duct static pressure to maintain the VAV box requiring the most static pressure at $90 \%$ open between its maximum and minimum values. The maximum value should be determined by the testing and balancing contractor in the field to provide design airflow in all VAV boxes. The minimum value is typically set as 124.5 Pascals (Ps) (0.5 inch water gauge) [14].

"Average" practice is to reset the duct static pressure based on outdoor-air temperature with a narrow reset range, i.e., the minimum set point at $80 \%$ of the maximum set point. Figure 6 shows the reset schedule for "average" practice. The summer design outdoor-air temperature in Figure 6 is the annual cooling design dry bulb temperature; for example, the $1 \%$ annual cooling design dry bulb temperature for Chicago IL is $32.17^{\circ} \mathrm{C}\left(89.9^{\circ} \mathrm{F}\right)$.

"Poor" practice is to use a constant duct static pressure set point that is determined by the testing, adjusting and balancing (TAB). 


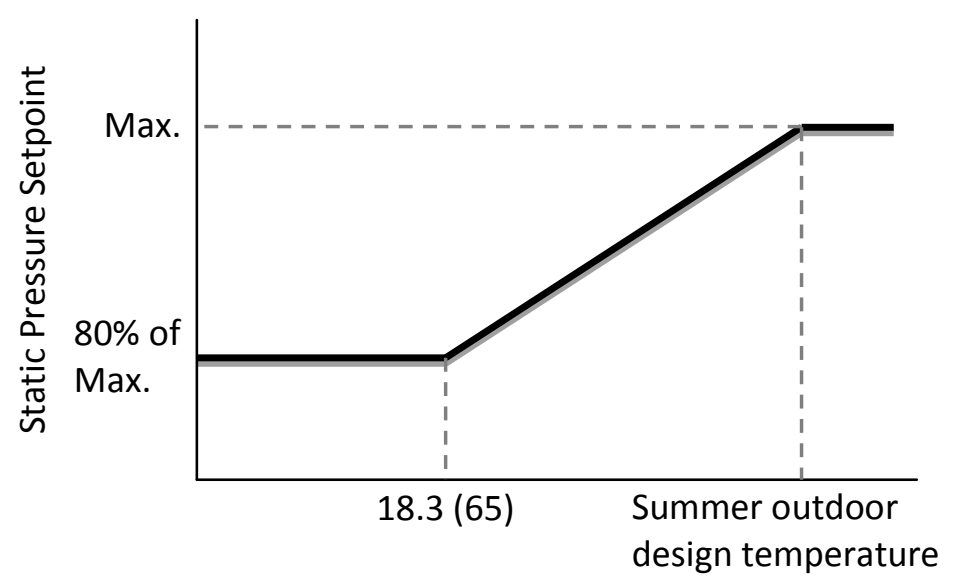

Outdoor Air Temperature, ${ }^{\circ} \mathrm{C}\left({ }^{\circ} \mathrm{F}\right)$

Figure 6. Duct static pressure reset schedule - "average practice"

Table 1. Summary of range of VAV system controls

\begin{tabular}{llll}
\hline \multicolumn{1}{c}{ Control Variables } & \multicolumn{1}{c}{ Good Practice } & \multicolumn{1}{c}{ Average Practice } & \multicolumn{1}{c}{ Poor Practice } \\
\hline Room cooling set point & $24.4^{\circ} \mathrm{C}\left(76^{\circ} \mathrm{F}\right)$ & $23.3^{\circ} \mathrm{C}\left(74^{\circ} \mathrm{F}\right)$ & $22.2^{\circ} \mathrm{C}\left(72^{\circ} \mathrm{F}\right)$ \\
\hline Room heating set point & $20.0^{\circ} \mathrm{C}\left(68^{\circ} \mathrm{F}\right)$ & $21.1^{\circ} \mathrm{C}\left(70^{\circ} \mathrm{F}\right)$ & $22.2^{\circ} \mathrm{C}\left(72^{\circ} \mathrm{F}\right)$ \\
\hline Night heating setback & $12.8^{\circ} \mathrm{C}\left(55^{\circ} \mathrm{F}\right)$ & $15.6^{\circ} \mathrm{C}\left(60^{\circ} \mathrm{F}\right)$ & $18.3^{\circ} \mathrm{C}\left(65^{\circ} \mathrm{F}\right)$ \\
\hline Night cooling setup & $32.2^{\circ} \mathrm{C}\left(90^{\circ} \mathrm{F}\right)$ & $29.4^{\circ} \mathrm{C}\left(85^{\circ} \mathrm{F}\right)$ & $26.7^{\circ} \mathrm{C}\left(80^{\circ} \mathrm{F}\right)$ \\
\hline VAV box minimum flow & $\begin{array}{l}\text { Dual max control } \\
\text { strategy }\end{array}$ & $\begin{array}{l}\text { Single max control with } \\
\text { min flow set at } 30 \%\end{array}$ & $\begin{array}{l}\text { Single max control with } \\
\text { min flow set at } 50 \%\end{array}$ \\
\hline Optimal start & $\begin{array}{l}\text { ASHRAE } 90.1-2010 \\
\text { minimum requirement }\end{array}$ & $\begin{array}{l}\text { Two hours before } \\
\text { occupancy }\end{array}$ & $\begin{array}{l}\text { Four hours before } \\
\text { occupancy }\end{array}$ \\
\hline Supply air temperature & $\begin{array}{l}\text { Reset base on warmest } \\
\text { zones between } 12.8^{\circ} \mathrm{C} \\
\left(55^{\circ} \mathrm{F}\right) \text { and } 18.3^{\circ} \mathrm{C}\left(65^{\circ} \mathrm{F}\right)\end{array}$ & $\begin{array}{l}\text { Reset based on outside- } \\
\text { air temperature between } \\
12.8^{\circ} \mathrm{C}\left(55^{\circ} \mathrm{F}\right) \text { and } 18.3^{\circ} \mathrm{C} \\
\left(65^{\circ} \mathrm{F}\right)\end{array}$ & $\begin{array}{l}\text { Constant supply air } \\
\text { temperature at } 11.7^{\circ} \mathrm{C} \\
\left(53^{\circ} \mathrm{F}\right)\end{array}$ \\
\hline Economizer & $\begin{array}{l}\text { Differential enthalpy } \\
\text { Minimum outside-air }\end{array}$ & $\begin{array}{l}\text { Differential dry bulb } \\
\text { temperature }\end{array}$ & $\begin{array}{l}\text { No economizer } \\
\text { intake }\end{array}$ \\
\hline controlled ventilation & $\begin{array}{l}15 \% \text { minimum outside air } \\
\text { damper position }\end{array}$ & $\begin{array}{l}30 \% \text { minimum outside air } \\
\text { damper position }\end{array}$ \\
\hline Duct static pressure & $\begin{array}{l}\text { Maintain worst-case } \\
\text { VAV box damper at } 90 \% \\
\text { open }\end{array}$ & $\begin{array}{l}\text { Reset based on outdoor } \\
\text { air temperature with } \\
\text { narrow reset range }\end{array}$ & $\begin{array}{l}\text { Constant at design set } \\
\text { point }\end{array}$ \\
\hline
\end{tabular}

\section{Modeling of Controls in EnergyPlus}

Modeling of the VAV system controls described in the previous sections can be complicated depending on the simulation software used. Some controls can be modeled explicitly using the dedicated components or modules in some building simulation software; others need workarounds or customized coding. 
EnergyPlus version 8.5 [38] was used in this study to model the controls. EnergyPlus is a detailed wholebuilding energy-simulation program that calculates a building's heating and cooling loads, disaggregates energy end use, and includes features to verify that simulations are consistent with a building's actual performance [38]. Recent enhancements to the program (the "EMS" module) allow control strategies to be specified by "line-code" control programs that are interpreted at run time, which gives the flexibility to use programmable supervisory control strategies [39].

Most of the controls discussed above can be simulated using EnergyPlus standard objects, e.g., the thermostat, the controller, the set point, and availability managers. Table 2 summarizes how the controls were implemented in EnergyPlus for this study. The duct static pressure reset could not be modeled explicitly because EnergyPlus employs steady-state models in the building systems simulation that are based on power required to meet set points. The program does not model the actuating devices that execute a control signal, e.g. damper or valve positions. Therefore, we combined physical and empirical approaches to simulate the duct static pressure reset. The variable speed fan model in EnergyPlus computes the fan power consumption by multiplying a part load factor (PLF) by the design fan power consumption. The PLF is calculated using a fourth order polynomial equation as a function of fan air flow fraction [38]:

$$
P L F=C_{1}+C_{2} \cdot F F+C_{2} \cdot F F^{2}+C_{3} \cdot F F^{3}+C_{4} \cdot F F^{4}+C_{5} \cdot F F^{5}
$$

Where, $\quad C_{1}$ to $C_{5}=$ constant coefficients in the fourth order polynomial curve,

$$
F F=\text { ratio of the fan air flow to the design fan air flow. }
$$

The performance curves presented in [14] were used in this study. These curves were developed using the Characteristic System Curve Fan Model developed by Stein and Hydeman [40]. They include part load performance of the fan, belt, motor and the Variable Speed Drive (VSD). Table 3 lists the coefficients for different duct static pressure reset practices.

Table 2. Summary of the implementation of controls in EnergyPlus (italicized items are EnergyPlus standard

\begin{tabular}{|c|c|c|c|}
\hline $\begin{array}{l}\text { Control } \\
\text { Variables }\end{array}$ & Good Practice & Average Practice & Poor Practice \\
\hline $\begin{array}{l}\text { Room air } \\
\text { temperature }\end{array}$ & $\begin{array}{l}\text { Use ZoneControl:Thermostat } \\
\text { in conjunction with } \\
\text { ThermostatSetpoint:DualSetp } \\
\text { oint, and apply room } \\
\text { temperature set point in the } \\
\text { Schedule:Compact that is } \\
\text { associated with the } \\
\text { ThermostatSetpoint:DualSetp } \\
\text { oint }\end{array}$ & Same as good practice & Same as good practice \\
\hline Night setback & $\begin{array}{l}\text { Apply setback schedule in } \\
\text { Schedule:Compact that is } \\
\text { associated with } \\
\text { ThermostatSetpoint:DualSetp }\end{array}$ & Same as good practice & $\begin{array}{l}\text { Apply setback schedule in } \\
\text { Schedule:Compact that is } \\
\text { associated with } \\
\text { ThermostatSetpoint:SingleHe }\end{array}$ \\
\hline
\end{tabular}
component models) 


\begin{tabular}{|c|c|c|c|}
\hline & oint & & atingOrCooling \\
\hline $\begin{array}{l}\text { VAV box } \\
\text { minimum } \\
\text { flow }\end{array}$ & $\begin{array}{l}\text { In } \\
\text { AirTerminal:SingleDuct:VAV:R } \\
\text { eheat, set "Damper Heating } \\
\text { Action" and the "Maximum } \\
\text { Flow Fraction During Heating" } \\
\text { fields to the proper values }\end{array}$ & $\begin{array}{l}\text { In } \\
\text { AirTerminal:SingleDuct:VAV:R } \\
\text { eheat, only set "Constant } \\
\text { Minimum Air Flow Fraction" } \\
\text { field to the proper value }\end{array}$ & Same as average practice \\
\hline Optimal start & $\begin{array}{l}\text { Use } \\
\text { AvailabilityManager:Optimu } \\
\text { mStart and choose } \\
\text { "AdaptiveTemperatureGradie } \\
\text { nt" in the field "Control } \\
\text { Algorithm" }\end{array}$ & $\begin{array}{l}\text { Set the HVAC operation } \\
\text { schedule two hours earlier } \\
\text { than the occupancy schedule }\end{array}$ & Same as average practice \\
\hline $\begin{array}{l}\text { Supply air } \\
\text { temperature }\end{array}$ & $\begin{array}{l}\text { Use } \\
\text { SetpointManager:Warmest }\end{array}$ & $\begin{array}{l}\text { Use } \\
\text { SetpointManager:OutdoorAir } \\
\text { Reset }\end{array}$ & $\begin{array}{l}\text { Use } \\
\text { SetpointManager:Scheduled }\end{array}$ \\
\hline Economizer & $\begin{array}{l}\text { Use Controller:OutdoorAir } \\
\text { and choose } \\
\text { "DifferentialEnthalpy" in the } \\
\text { field "Economizer Control } \\
\text { Type" }\end{array}$ & $\begin{array}{l}\text { Use Controller:OutdoorAir } \\
\text { and choose } \\
\text { "DifferentialDryBulb" in the } \\
\text { field "Economizer Control } \\
\text { Type" }\end{array}$ & $\begin{array}{l}\text { Use Controller:OutdoorAir } \\
\text { and choose "NoEconomizer" } \\
\text { in the field "Economizer } \\
\text { Control Type }\end{array}$ \\
\hline $\begin{array}{l}\text { Minimum } \\
\text { outdoor air } \\
\text { intake }\end{array}$ & $\begin{array}{l}\text { Use Controller:OutdoorAir in } \\
\text { conjunction with } \\
\text { Controller:MechanicalVentilat } \\
\text { ion. }\end{array}$ & $\begin{array}{l}\text { Use Controller:OutdoorAir } \\
\text { and specify Minimum } \\
\text { Outdoor Air Flow Rate to be } \\
10 \% \text { more than designed }\end{array}$ & $\begin{array}{l}\text { Use Controller:OutdoorAir } \\
\text { and specify Minimum } \\
\text { Outdoor Air Flow Rate to be } \\
30 \% \text { more than designed. }\end{array}$ \\
\hline $\begin{array}{l}\text { Duct static } \\
\text { pressure }\end{array}$ & $\begin{array}{l}\text { Use the good-reset } \\
\text { coefficients listed in Table } 3\end{array}$ & $\begin{array}{l}\text { Use the average-reset } \\
\text { coefficients listed in Table } 3\end{array}$ & $\begin{array}{l}\text { Use the no-reset coefficients } \\
\text { listed in Table } 3\end{array}$ \\
\hline
\end{tabular}

Table 3 Coefficient for different duct static pressure reset practices

\begin{tabular}{llllll}
\hline Performance & $\boldsymbol{C}_{\mathbf{1}}$ & $\boldsymbol{C}_{\boldsymbol{2}}$ & $\boldsymbol{C}_{\mathbf{3}}$ & $\boldsymbol{C}_{\mathbf{4}}$ & $\boldsymbol{C}_{\boldsymbol{5}}$ \\
\hline Perfect duct pressure reset & 0.027827882 & 0.026583195 & -0.0870687 & 1.03091975 & 0 \\
\hline Good duct pressure reset & 0.040759894 & 0.08804497 & -0.07292612 & 0.943739823 & 0 \\
\hline Average duct pressure reset & 0.047182815 & 0.130541742 & -0.117286942 & 0.940313747 & 0 \\
\hline No duct pressure reset & 0.070428852 & 0.385330201 & -0.460864118 & 1.00920344 & 0 \\
\hline
\end{tabular}

\section{Simulation}

\subsection{Model description}

The U.S. Department of Energy has developed 15 reference-building models of three vintages (new, pre1980, and post-1980 construction), which encompass most of the commercial building stock across 16 locations (representing all U.S. climate zones) [41]. The reference-building models represent 
approximately $70 \%$ of commercial building energy use based on the 2003 Commercial Building Energy Consumption Survey (CBECS) [42]. These models have been carefully developed and reviewed by several researchers to increase confidence in their use [41].

This study used the new-construction medium-size office building reference model. Table 4 lists general information about the building, and Figure 7 shows the building geometry and typical floor plan. Three packaged direct-Expansion rooftop VAV air-handling units with gas furnaces serve the reference building. The model employs electric reheat for the VAV terminal boxes, which is uncommon in commercial buildings, so we modified the model to use hot-water reheat for the VAV terminal boxes.

Table 4. Reference building information

\begin{tabular}{ll}
\hline Building Characteristics & Value \\
\hline Total floor area (square meters $\left.\left[\mathrm{m}^{2}\right]\right)$ & 4,982 \\
\hline Occupant density $\left(\mathrm{m}^{2} / \mathrm{per}\right)$ & 18.58 \\
\hline Lighting load $\left(\right.$ Watts $\left.[\mathrm{W}] / \mathrm{m}^{2}\right)$ & 10.16 \\
\hline Plug load $\left(\mathrm{W} / \mathrm{m}^{2}\right)$ & 10.16 \\
\hline Aspect Ratio & 1.5 \\
\hline Number of Floors & 3 \\
\hline Window Fraction (window-to-wall Ratio) & 0.33 \\
\hline Floor-to-Ceiling Height (m) & 2.74 \\
\hline Floor-to-Floor Height (m) & 4 \\
\hline Building Fabric & 2003 CBECS [34] \\
\hline
\end{tabular}
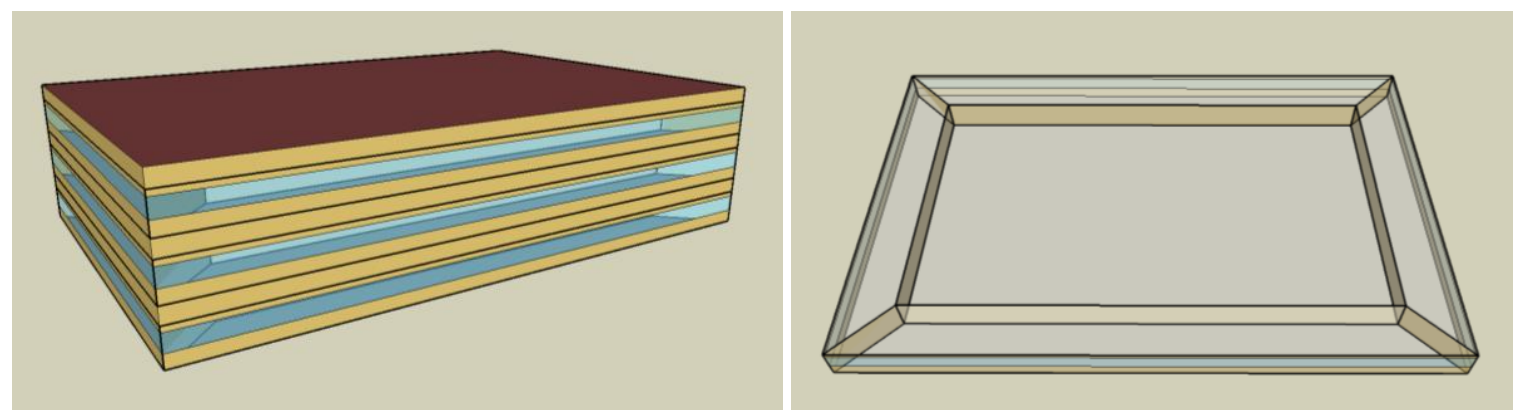

Figure 7. Reference building geometry and thermal zones

\subsection{Methodology}

A sensitivity analysis was performed to investigate the impact of individual control variables on annual energy consumption. We used the differential sensitivity analysis method described by Lomas and Eppel [43]. This method varies a single variable in each simulation while the other variables remain at their base values, so the change in a predicted parameter is a direct measure of the effect of the change made in that variable. The U.S. Department of Energy reference models were parametrically varied to account for the variation in the control variables defined in Table 1. Two U.S. climate zones, cold 
(represented by Chicago IL) and hot-humid (represented by Houston TX), were used. The jEPlus [44] tool was used for parametric simulations. Two cases with all control variables set to the good and the poor practices were also created to demonstrate the "combined effect".

Monte Carlo analysis [43] was applied to capture the distribution of the annual energy consumption resulting from variation in the system controls. The analysis assumes discrete uniform distribution for each control variable among the three operational practices listed in Table 1. We defined the good practice $=1$, average practice $=2$ and poor practice $=3$, and they have equal probability $1 / 3$. All possible combinations of the 10 control variables would be $59,049\left(3^{\wedge} 10\right)$ samples. Currently, there are no empirically based recommendations regarding the required number of samples to produce reasonable results when using Monte Carlo Simulation [45]. We started with 200 samples randomly generated using Latin Hypercube Sampling [46] and gradually increased the number of the samples. We found that the mean and standard deviation of the output results remain unchanged $\left(e<10^{-6}\right)$ after 800 samples. Therefore, 1,000 randomly generated samples were used in this study.

\subsection{Results and Discussion}

Source energy [47] was used to combine the electricity and gas consumption of the building. The results were then normalized to the source energy computed by the model with all control variables at the "average practice" settings. A negative value indicates a percentage reduction in energy use, and a positive value indicates a percentage increase in energy use. Figures 8 and 9 show the sensitivity analysis results of the individual control variables for Houston and Chicago, respectively. The results are presented in descending order with the most sensitive variable on the left, and the combined effect of all control variables at "good practice" and "poor practice" settings at the far right. The results are further broken down into three end-use categories, heating (the boiler and the hot water pump), cooling (the DX cooling systems) and fan (the air handling unit fans), and shown in Table 5 and Table 6 for Houston and Chicago, respectively. The number in each end-use category represents its contribution to the total percentage change.

The VAV box minimum airflow setting is the most sensitive control variable for both Houston and Chicago as shown in the figures. The "poor" VAV box minimum airflow setting can result in $14.3 \%$ energy penalty in Houston, of which $43.4 \%$ is attributed to the cooling energy increase, $39.4 \%$ is attributed to the heating energy increase, and $17.2 \%$ is attributed to the fan energy increase. The energy penalty in Chicago is $10.6 \%$, of which $33.6 \%$ is attributed to the cooling energy increase, $38.1 \%$ is attributed to the heating energy increase, and $28.3 \%$ is attributed to the fan energy increase. The "good" VAV box minimum airflow setting can lead to $3.62 \%$ total energy savings in Houston, of which $56.3 \%$ comes from the cooling energy reduction, $31.8 \%$ comes from the heating energy reduction, and $11.9 \%$ comes from the fan energy reduction. The energy savings in Chicago is $2.19 \%$, of which $41.3 \%$ comes from the cooling energy reduction, $24.7 \%$ comes from the heating energy reduction, and $34.0 \%$ comes from the fan energy reduction.

The night heating setback and cooling setup are the least sensitive control variables in both cities. The effect of the night cooling setup is negligible for both. The effect of the night heating setback for 
Houston is negligible, and for Chicago the "good practice" night heating seat back can result in $0.3 \%$ energy savings while the "poor practice" night heating setback can result in a $1.0 \%$ energy penalty.

The combined effects of all "good" and "poor" practices are similar in both cities, with $51.7 \%$ and $53.0 \%$ energy penalties and $12.2 \%$ and $13.5 \%$ energy savings in Houston and Chicago, respectively. We conclude that the variation in VAV system performance that is attributable to variations in system controls is as much as $63.9 \%$ and $66.5 \%$ for the category of "average" practices in Houston and Chicago, respectively. This significant variation resulting from differences in controls indicates that clearly defining the VAV controls is critical for use cases that use a VAV system as a baseline.

Figures 10 and 11 show the frequency distributions of the Monte Carlo analysis for Houston and Chicago, respectively. The distribution in the normalized annual source-energy consumption follows a near-lognormal distribution. The geometric means of the resulting probability density functions for both cities approximate 1.0, which represents "average" practice. Based on the density function, researchers and engineers could decide a reasonable percentile to use in representing the baseline performance of a VAV system. For example, in this study, if $10 \%$ is used, the normalized annual source-energy consumptions are $93.2 \%$ and $94.2 \%$ for Houston and Chicago, respectively, which means the selected controls in the VAV system outperform $90 \%$ of all VAV systems in the two cities in terms of controls. The extreme case would be using our "good" practice results to represent best-case VAV system performance.
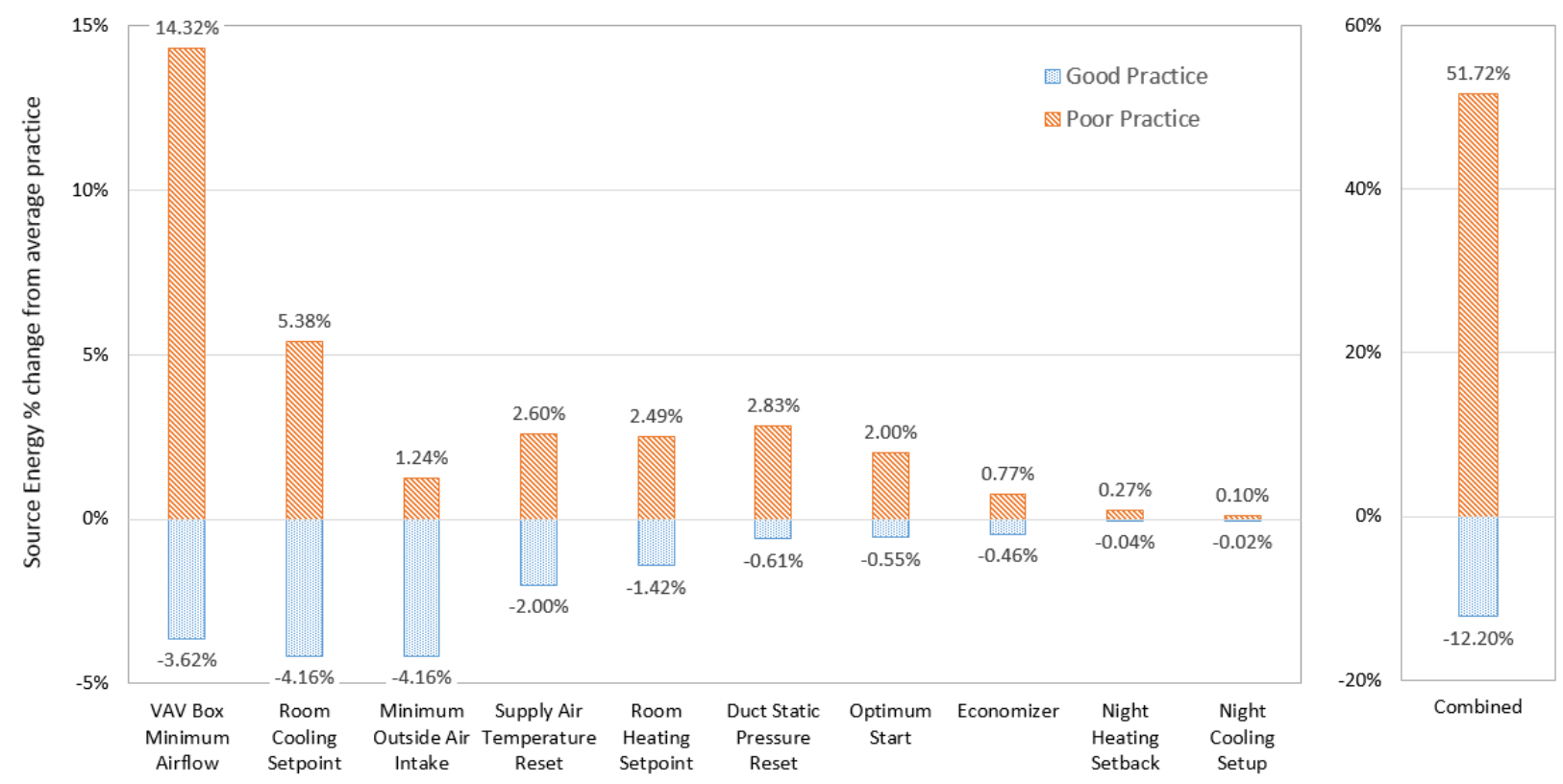

Figure 8. Sensitivity analysis results - Houston 

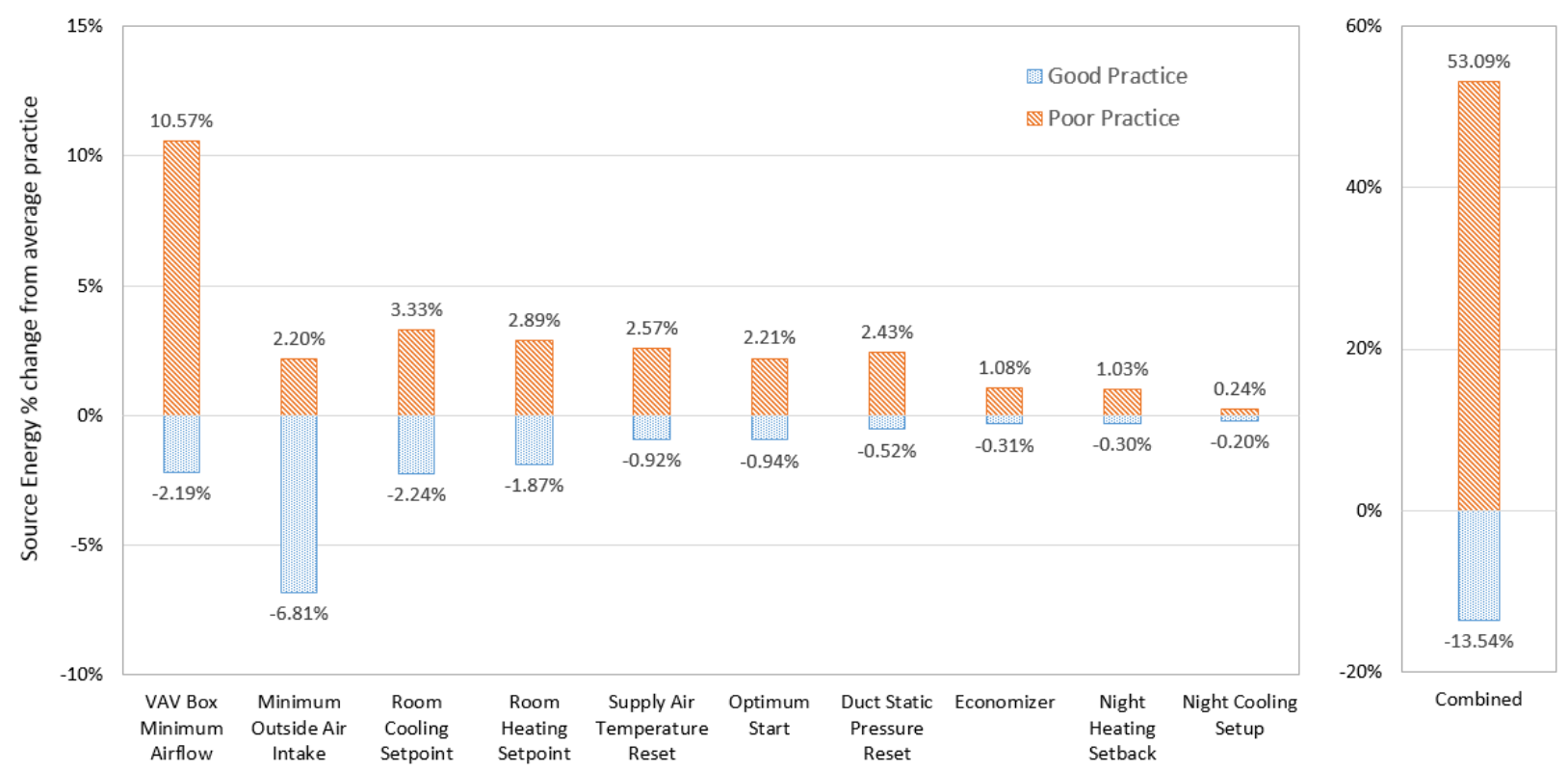

Figure 9. Sensitivity analysis results - Chicago

Table 5 Results breakdown for Houston

\begin{tabular}{l|c|ccc|c|ccc}
\hline \multirow{2}{*}{\multicolumn{1}{c}{ Control Strategy }} & \multicolumn{3}{|c|}{ Good Practice (\%) } & \multicolumn{3}{c}{ Poor Practice (\%) } \\
\cline { 2 - 8 } & Total & Cooling & Heating & Fans & Total & Cooling & Heating & Fans \\
\hline VAV Box Min. Airflow & $\mathbf{- 3 . 6 2}$ & 56.3 & 31.8 & 11.9 & $\mathbf{1 4 . 3 2}$ & 43.4 & 39.4 & 17.2 \\
Min. Outside Air Intake & $\mathbf{- 4 . 1 6}$ & 85.8 & 14.2 & 0 & $\mathbf{1 . 2 4}$ & 76.6 & 23.4 & 0 \\
Room Heating Set point & $\mathbf{- 4 . 1 6}$ & 68.4 & 16.5 & 15.1 & $\mathbf{5 . 3 8}$ & 59.1 & 25.8 & 15.1 \\
Room Cooling Set point & $\mathbf{- 1 . 4 2}$ & 7.7 & 90.8 & 1.5 & $\mathbf{2 . 4 9}$ & 12.1 & 85.4 & 2.5 \\
SAT Reset & $\mathbf{- 2 . 0 0}$ & 203.4 & 61 & -164.4 & $\mathbf{2 . 6 0}$ & 58.3 & 49.1 & -7.4 \\
Optimum Start & $\mathbf{- 0 . 5 5}$ & 24.4 & 70.7 & 4.9 & $\mathbf{2 . 0 0}$ & 53.5 & 37.1 & 9.4 \\
Duct Static Pressure Reset & $\mathbf{- 0 . 6 1}$ & 26.2 & -2.3 & 76.1 & $\mathbf{2 . 8 3}$ & 26.3 & -2.3 & 76.0 \\
Economizer & $\mathbf{- 0 . 4 6}$ & 99.7 & 0.3 & 0 & $\mathbf{0 . 7 7}$ & 100.4 & -0.4 & 0 \\
Night Heating Setback & $\mathbf{- 0 . 0 4}$ & 0.2 & 60.3 & 39.5 & $\mathbf{0 . 2 7}$ & 0.1 & 69.9 & 30.0 \\
Night Cooling Setup & $\mathbf{- 0 . 0 2}$ & -728.1 & 757.9 & 70.2 & $\mathbf{0 . 1 0}$ & -50.6 & 117.5 & 33.1 \\
Combined & $\mathbf{- 1 2 . 2}$ & 81.3 & 24.5 & -5.8 & $\mathbf{5 1 . 7 2}$ & 43.0 & 44.0 & 13.0 \\
\hline
\end{tabular}


Table 6 Results breakdown for Chicago

\begin{tabular}{|c|c|c|c|c|c|c|c|c|}
\hline \multirow{2}{*}{ Control Strategy } & \multicolumn{4}{|c|}{ Good Practice (\%) } & \multicolumn{4}{|c|}{ Poor Practice (\%) } \\
\hline & Total & Cooling & Heating & Fans & Total & Cooling & Heating & Fans \\
\hline VAV Box Min. Airflow & -2.19 & 41.3 & 24.7 & 34.0 & 10.57 & 33.6 & 38.1 & 28.3 \\
\hline Min. Outside Air Intake & -6.81 & 11.2 & 88.8 & 0 & 2.20 & 9.4 & 90.5 & 0 \\
\hline Room Heating Set point & -2.24 & 62.9 & 7.4 & 29.7 & 3.33 & 49.3 & 22.9 & 27.8 \\
\hline Room Cooling Set point & -1.87 & 3.3 & 94.0 & 2.7 & 2.89 & 6.3 & 89.3 & 4.4 \\
\hline SAT Reset & -0.92 & 280.7 & 66.8 & -247.5 & 2.57 & 40.8 & 56.1 & 3.1 \\
\hline Optimum Start & -0.94 & -22.4 & 135.5 & -13.1 & 2.21 & 12.6 & 78.7 & 8.7 \\
\hline Duct Static Pressure Reset & -0.52 & 18.1 & -16.3 & 98.2 & 2.43 & 18.2 & -16.0 & 97.8 \\
\hline Economizer & -0.31 & 99.9 & 0.2 & -0.1 & 1.08 & 100.2 & -0.2 & 0 \\
\hline Night Heating Setback & -0.30 & 0 & 66.7 & 33.3 & 1.03 & 0 & 74.0 & 26.0 \\
\hline Night Cooling Setup & -0.20 & -10.2 & 38.9 & 71.3 & 0.24 & 35.1 & 28.5 & 36.4 \\
\hline Combined & -13.54 & 33.7 & 63.8 & 2.5 & 53.09 & 34.5 & 50.1 & 15.4 \\
\hline
\end{tabular}

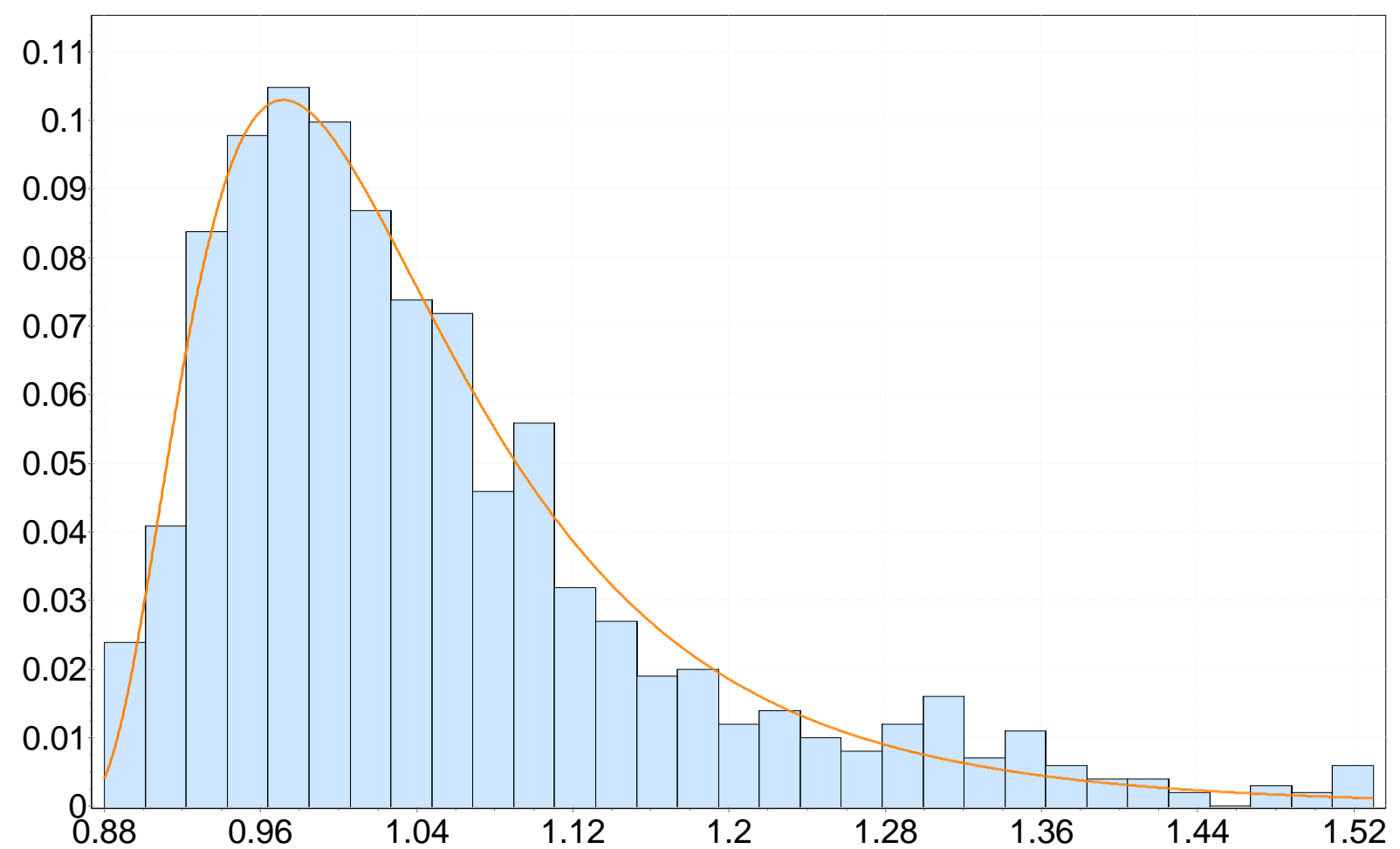

Figure 10. Monte Carlo analysis results - Houston 


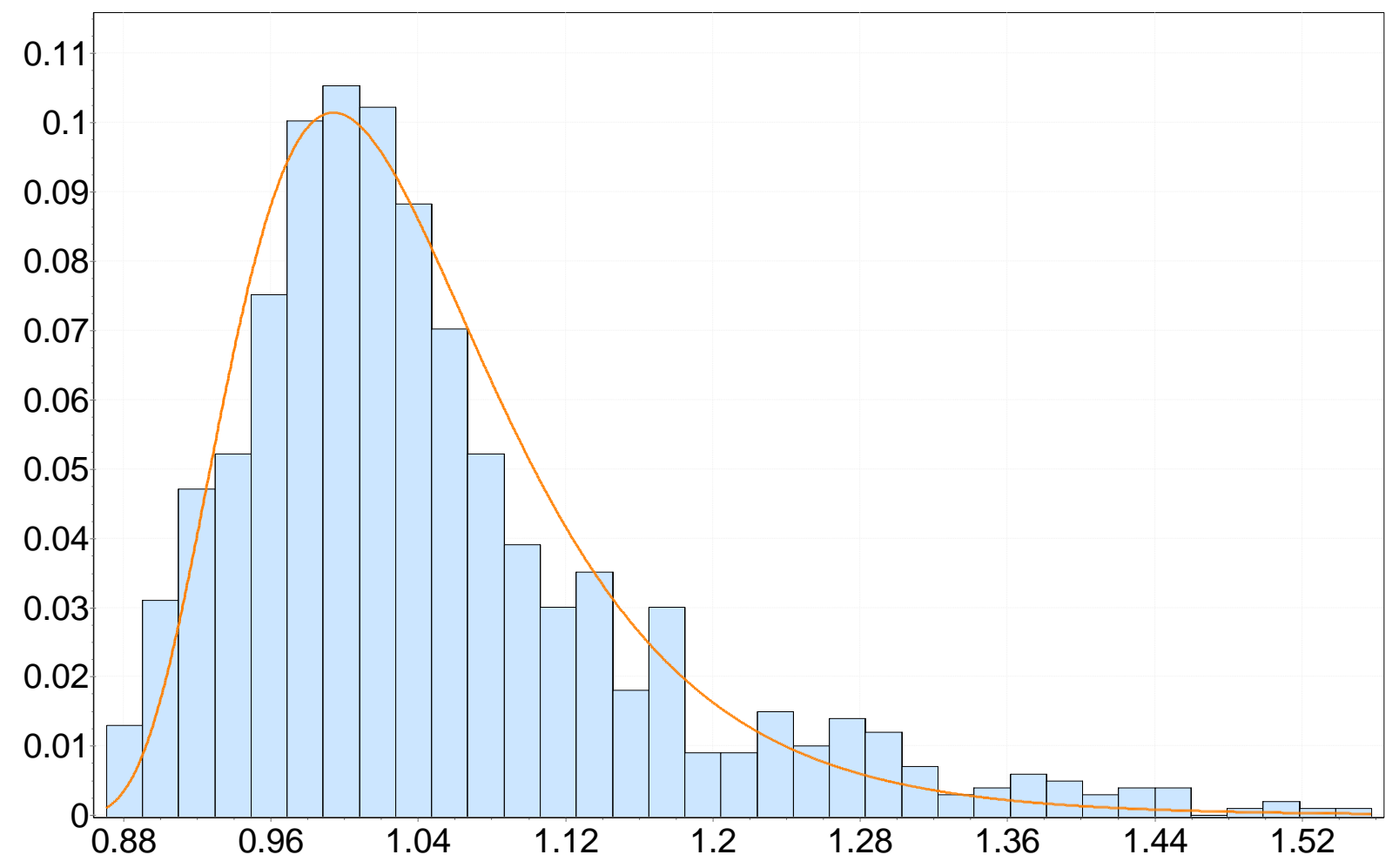

Figure 11. Monte Carlo analysis results - Chicago

\section{Summary}

The energy performance of VAV systems varies significantly because of variations among system controls. To characterize this variation, we defined a range of operational practices ("good," "average," and "poor") for the control variables of a conventional VAV system and investigated the differences among these practices using the United States Department of Energy reference medium-size office building in two types of climates, represented by Chicago IL and Houston TX. We found that VAV system energy performance varies by as much as $63.9 \%$ and $66.5 \%$, respectively for the two cities with "average" control practices. Therefore, we conclude that it is critical to clearly define system controls when comparing VAV systems to other technologies and systems.

Our study presents an approach to using a probability density function to determine a reasonable baseline performance of VAV systems. The results show that the distribution in the annual sourceenergy consumption resulting from variations in system controls follows a near-log-normal distribution. The geometric mean of the resulting probability density function approximates 1.0 , which represents average practice.

\section{Acknowledgment}

This work was supported by the Assistant Secretary for Energy Efficiency and Renewable Energy, Building Technologies Office, of the U.S. Department of Energy under Contract No. DE-AC02-05CH11231. 


\section{References}

1. ASHRAE Handbook. HVAC systems and equipment, American Society of Heating, Refrigerating, and Air Conditioning Engineers, Atlanta GA, 2012.

2. Okochi, G. S. and Y. Yao, A review of recent developments and technological advancements of variable-air-volume (VAV) air-conditioning systems, Renewable and Sustainable Energy Reviews, 59 (2016) 784-817

3. Yao, Y., Z. Lian, W. Liu, Z. Hou and M. Wu, Evaluation program for the energy-saving of variableair-volume systems, Energy and Buildings 39 (2007) 558-568.

4. Zhou, Y. P., J. Y. Wu, R. Z. Wang and S. Shiochi, Energy simulation in the variable refrigerant flow air-conditioning system under cooling conditions, Energy and Buildings 39 (2007) 212-220.

5. Aynur, T. N., Y. Hwang and R. Radermacher, Simulation comparison of VAV and VRF air conditioning systems in an existing building for the cooling season. Energy and Buildings 41 (2009) 1143-1150.

6. Sastry, G. and P. Rumsey, VAV vs. Radiant Side-by-Side Comparison, ASHRAE Journal 56(5) (2014) $16-18,20,22-24$.

7. Ke, Y. and S. A. Mumma, Optimized supply-air temperature (SAT) in variable-air-volume (VAV) systems, Energy 22 (6) (1997) 601-614.

8. Engdahl, F. and D. Johansson, Optimal supply air temperature with respect to energy use in a variable air volume system, Energy and Buildings 36(3) (2004) 205-218.

9. Nassif, N. and S. Moujaes, A new operating strategy for economizer dampers of VAV system, Energy and Buildings 40(3) (2008) 289-299.

10. Ke, Y. P. and S. A. Mumma, Variable air volume ventilation control strategies analysed in six climate zones, International Journal of Energy Research, 23(5) (1999) 371-387.

11. Wang, S. and J. Burnett, Variable-air-volume air-conditioning system: Optimal reset of static pressure setpoint, Building Services Engineering Research \& Technology 19(4) (1998) 219-231.

12. Shim, G., L. Song and G. Wang, Comparison of different fan control strategies on a variable air volume systems through simulations and experiments, Building and Environment 72 (2014) 212222.

13. Sekhar, S. C., A critictal evaluation of variable air volume system in hot and humid climate, Energy and Buildings 26 (1997) 223-232

14. Hydeman, M., S. Taylor, J. Stein, E. Kolderup and T. Hong, Advanced variable air volume: system design guide: design guidelines, California Energy Commission, 2003.

15. Liu, M., D. Claridge and W. Turner, Continuous Commissioning Guidebook for Federal Energy Managers, Federal Energy Management Program, U.S. Department of Energy, 2001.

16. Pang, X., B. Zheng and M. Liu, Case study of Continuous Commissioning in an office building, Proceedings of the $6^{\text {th }}$ International Conference for Enhanced Building Operations, 2006, Shenzhen, China.

17. Deru, M., Field K., D. Studer, K. Benne, B. Griffith, P. Torcellini, B. Liu, M. Halverson, D. Winiarski, M. Rosenberg, M. Yazdanian, J. Huang and D. Crawley, U.S. Department of Energy commercial reference building models of the national building stock. Technical Report, NREL/TP-5500-46861, 2011.

18. University of California, San Diego: http://sustainability.ucsd.edu/involve/temperaturesettings.html.

19. University of Maryland, College Park: http://www.sustainability.umd.edu/content/about/policies.php.

20. Harvard University: http://green.harvard.edu/topics/energy-emissions/temperature-policy.

21. Columbia University: http://policylibrary.columbia.edu/indoor-space-temperature-guidelines. 
22. Minneapolis City of Lakes: Policy on indoor Space Temperature:

http://www.ci.minneapolis.mn.us/www/groups/public/@citycoordinator/documents/webconte nt/convert_258024.pdf.

23. California Orange County: Energy Conservation Policy: http://www.orangecountync.gov/document_center/DEAPR/EnergyPolicy.pdf.

24. ASHRAE, ANSI/ASHRAE Standard 55-2004/2010: Thermal Environmental Conditions for Human Occupancy. ASHRAE, Atlanta, GA.

25. U.S. Department of Labor, Occupational Safety \& Health Administration Technical Manual Section III Chapter 2 Indoor Air Quality Investigation part V. Recommendations for the Employer, Washington, DC.

26. ASHRAE, ASHRAE/IESNA Standard 90.1-2013: Energy Standard for Buildings Except Low-Rise Residential Buildings, ASHRAE, Atlanta, GA, 2013.

27. Szydlowski, R. F., L. E. Wrench and P. J. O’Neill, Measured energy savings from using night temperature setback, The World Energy Engineering Conference, Atlanta, GA, Oct 28-30, 1992.

28. Guo, W. and D. W. Nutter, Setback and setup temperature analysis for a classic double-corridor classroom building. Energy and Buildings 42(2) (2010) 189-197.

29. Stein, J, Specifying VAV boxes, HPAC Heating, Piping, Air Conditioning Engineering, 77(11) (2005) 40-44.

30. Taylor, S., T. J. Stein, G. Paliaga and H. Cheng, Dual maximum VAV box control logic. ASHRAE Journal 54(12) (2012.) 16-24.

31. Cho, Y. H. and M. Liu, Minimum airflow reset of single duct VAV terminal boxes, Building and Environment 44 (2009) 1876-1885.

32. Yang, I. H., M. S. Yeo and K. W. Kim, Application of artificial neural network to predict the optimal start time for heating system in building, Energy conversion and management 44 (17) (2003) 2791-2809.

33. Florez, J. and G. C. Barney, Adaptive control of central heating systems: part 1: optimum start time control, Applied mathematical modeling 11(2) (1987) 89-95.

34. Seem, J, P. Armstrong and C. Hancock, Algorithms for predicting recovery time from night setback, ASHRAE Transactions 95(2) (1989) 439-44.

35. Gonzalez, R., Energy management with building automation, ASHRAE Journal 49(1) (2007) 26-32.

36. Bradshaw, G., Recommissioning for low cost and big savings, Energy Managers' Quarterly, Newsletter, Fouth Quarter, 2008.

http://bea.touchstoneenergy.com/sites/beabea/files/PDF/Energy/RecommissioningforLowCost andBigSavings.pdf

37. ASHRAE, ASHRAE Handbook: HVAC systems and equipment. ASHRAE, Atlanta GA, 2012.

38. U.S. Department of Energy, EnergyPlus 8.5 Documentation, Washington, DC, 2016.

39. Ellis, P. G., P. A. Torcellini and D. B. Crawley, Simulation of energy management systems in EnergyPlus, Proceedings of Building Simulation, Beijing, China, Sep 3-6, 2007.

40. Stein, J and M. M. Hydeman, Development and testing of the characteristic curve fan model, ASHRAE Transactions, 110(1) (2004) 347-356.

41. Torcellini, P., M. Deru, B. Griffith and K. Benne, DOE commercial building benchmark models, Proceedings of ACEEE Summer Study on Energy Efficiency in Buildings, Aug 17-22, 2008, Pacific Grove, CA.

42. U.S. Energy Information Administration, 2003 commercial buildings energy consumption survey, Washington, DC: http://www.eia.doe.gov/emeu/cbecs/cbecs2003/introduction.html.

43. Lomas, K. J. and H. Eppel, Sensitivity analysis techniques for building thermal simulation programs, Energy and Buildings 19 (1992) 21-44. 
44. Zhang, Y. and I. Korolija, Performing complex parametric simulation with jEPLUS, $9^{\text {th }}$ International Conference on Sustainable Energy Technologies, Aug 24-27, 2010, Shanghai, China.

45. Mundform, D. J., J. Schaffer, M. Kim, D. Shaw and A. Thongteeraparp, Number of replications required in Monte Carlo simulation studies: A synthesis of four studies, Journal of Modern Applied Statistical Methods 10(1) (2011) 19-28

46. McKay, M. D., R. J. Beckman and W. J. Conover, A comparison of three methods for selecting values of input variables in the analysis of output from a computer code, Technometrics 21 (1979) 239-245.

47. Deru, M. and P. Torcellini, Source energy and emission factors for energy use in buildings, Technical report, NREL/TP-500-38617, 2007. 